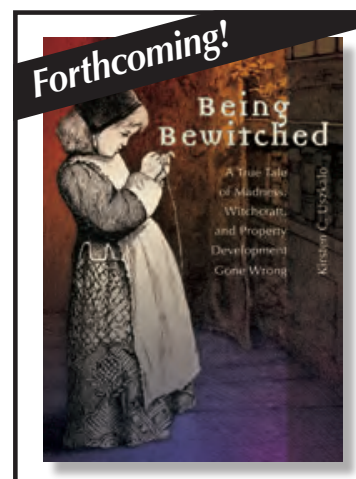

\title{
Being Bewitched
}

A True Tale of Madness, Witchcraft, and Property Development Gone Wrong Kirsten C. Uszkalo • Early Modern Studies, vol. 20 \$50.00 libr 9781612481654 • \$39.99 ebook 9781612481661 In 1622, thirteen-year-old Elizabeth Jennings fell strangely ill. After doctors' treatments proved useless, her family began to suspect the child had been bewitched, a suspicion that was confirmed when Elizabeth accused their neighbor Margaret Russell of witchcraft. In the events that followed, witchcraft hysteria intertwines with family rivalries, property disputes, and a web of supernatural beliefs.

\section{Renaissance Art \& Science @ Florence}

Susan B. Puett \& J. David Puett

Early Modern Studies, vol. 17

\$35.00 pbk 9781612481388 • \$29.99 ebook 9781612481852

The creativity of the human mind was brilliantly displayed during the Florentine Renaissance when artists, mathematicians, astronomers, apothecaries, architects, and others embraced the interconnectedness of their disciplines.

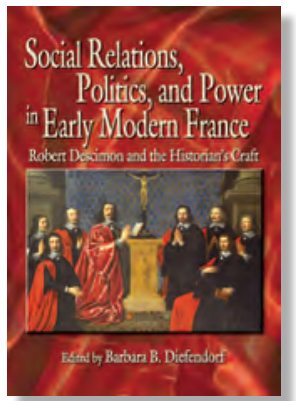

\section{Social Relations, Politics, and Power in Early Modern France}

Robert Descimon and the Historian's Craft

Barbara B. Diefendorf • Early Modern Studies, vol. 19

\$50.00 libr 9781612481630 •\$39.99 ebook 9781612481647

The study of history is a fundamentally sociable practice, with the exchange of ideas taking place in writing, over the seminar table, and often in informal discussions over food.

\section{Discounts available@tsup.truman.edu

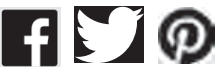

TRADITIONAL PUBLISHING FOR THE MODERN WORLD

Truman State University Press

tsup.truman.edu • 660.785.7336 • 100 E. Normal Ave., Kirksville, MO 63501 


\section{\&W \\ Early Modern Women An Interdisciplinary Journal}

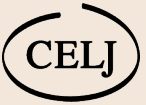

\section{Winner of the 2013 Council of Editors of Learned Journals Voyager Award}

for excellence in journals covering the period 1500-1800

Invites submissions of articles on the topic of women and gender in the early modern period, $1400-1750$. The Journal offers a yearly award of $\$ 1000$ for the best article in each volume.

Early Modern Women: An Interdisciplinary Journal is the only journal devoted solely to the interdisciplinary and global study of women and gender during the years 1400 to 1750 . Each volume gathers essays on early modern women from every country and region, by scholars from a wide range of academic disciplines, including art history, cultural studies, music, history, languages and literatures, political science, religion, theatre, history of science, and history of philosophy.

Editors:

Anne J. Cruz, Professor of Spanish

ajcruz@miami.edu

Mary Lindemann, Professor of History

mlindemann@miami.edu

Mihoko Suzuki, Professor of English

msuzuki@miami.edu

Center for the Humanities

University of Miami

Coral Gables, FL 33146

http://humanities.miami.edu/publications/emwj

To subscribe to the journal, send an email to: emwjournal@asu.edu

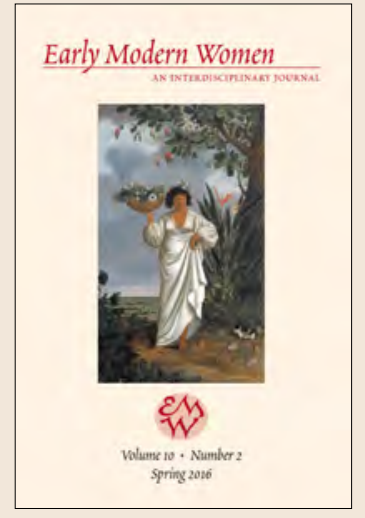

Early Modern Women
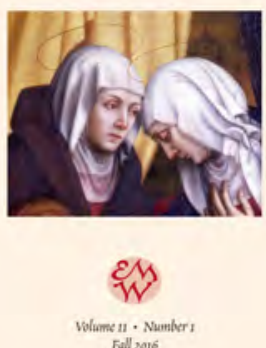


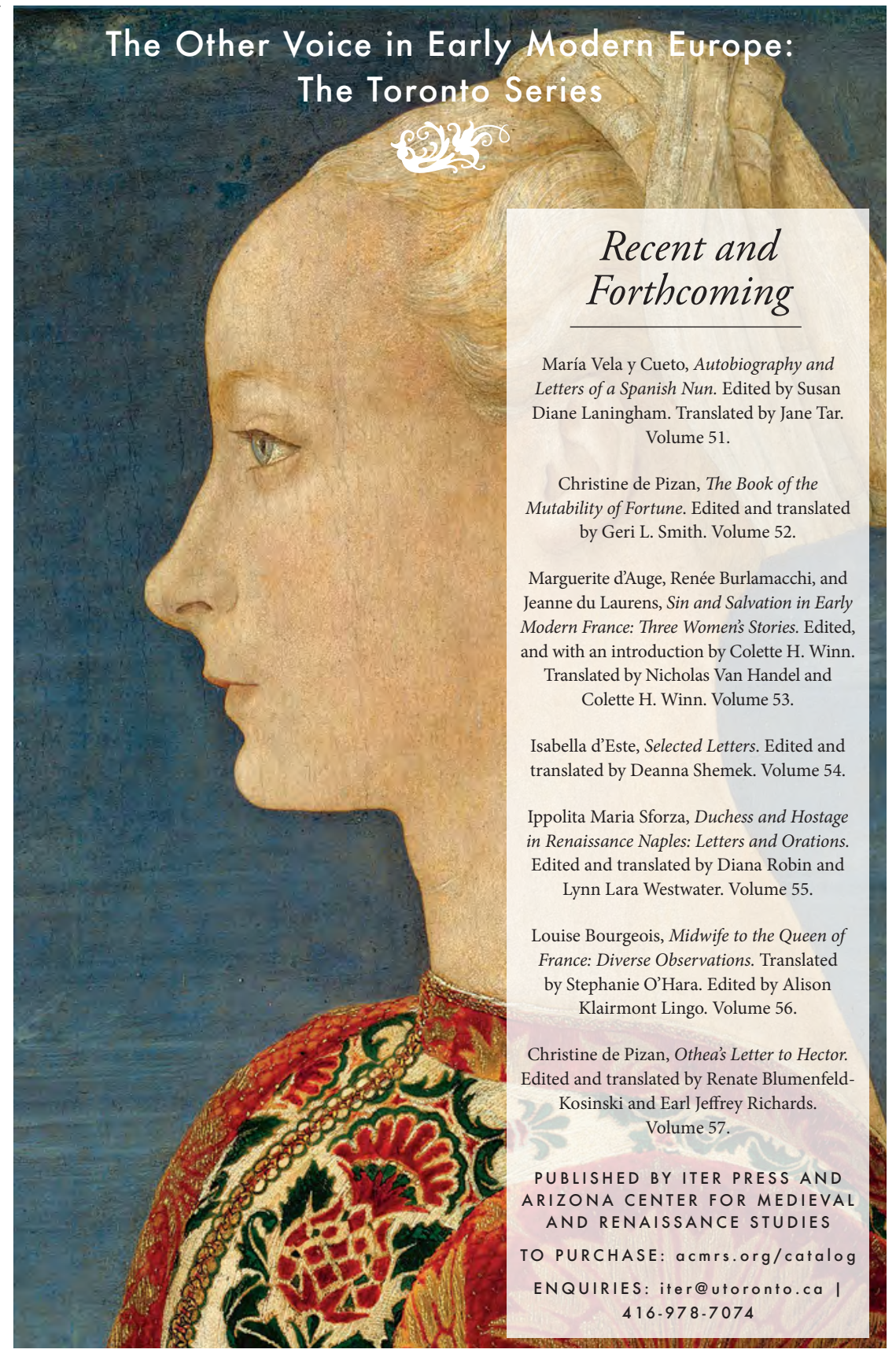

